\title{
Explant type and stress treatment determine the uni- and multicellular origin of somatic embryos in the tree fern Cyathea delgadii Sternb.
}

\author{
Małgorzata Grzyb ${ }^{1}$ (D) Anna Mikuła ${ }^{1}$
}

Received: 2 May 2018 / Accepted: 7 October 2018 / Published online: 11 October 2018

(c) The Author(s) 2018

\begin{abstract}
Cyathea delgadii is the first fern species for which somatic embryogenesis (SE) has recently been described. With this discovery, a new experimental model for exploration of SE was found. In this study, the effect of explant type (stipe and internode), length and diameter of the explant-donor frond, and stress treatment (by sucrose and air desiccation) on somatic embryo origin and SE efficiency was studied. In control culture, somatic embryos originated from single cells of stipe explants, whereas those induced on internodes were of multicellular origin. Although the activation of cell divisions was more abundant and the formation of somatic embryos occurred earlier in a culture of internodes than of stipe explants, the morphogenic capacity of internodes was much smaller. On their surface, the groups of competent cells formed protuberances that give rise to only three somatic embryos per internode. In contrast, almost $92 \%$ of stipe explants that were excised from the first frond, measuring $10 \mathrm{~mm}$ in length and less than $300 \mu \mathrm{m}$ in diameter, produced an average of 21 somatic embryos. Stipes treated with sucrose were not able to SE. More than fourfold increase in SE efficiency was obtained on internodes by their treatment with $0.4 \mathrm{M}$ sucrose for $45 \mathrm{~min}$. It was achieved by changing the pathway of somatic embryo differentiation from multicellular to unicellular. These results provide an excellent basis for further research on the mechanism of SE induction associated with a single- and multi-cell proliferation, especially that both types of the embryogenic pathway can occur on the same hormone-free medium.
\end{abstract}

Keywords Air desiccation $\cdot$ Hormone-free medium $\cdot$ Internode and stipe explants $\cdot$ Microscopic analysis $\cdot$ Somatic embryogenesis $\cdot$ Sucrose treatment

\section{Introduction}

Somatic embryogenesis (SE) is a remarkable expression of cellular totipotency, by which plant somatic cells undergo reprogramming and acquire the competence to assume a new developmental fate. In this process, somatic embryos may develop directly from cells of explant, or indirectly with an intermediate callus phase (Williams and Maheswaran 1986). In direct SE, depending on the relationship between neighbouring cells within the explant, the embryos are able to initiate from a single cell (Choi et al. 1998; Mikuła et al.

Communicated by M. I. Beruto.

Małgorzata Grzyb

m.grzyb@obpan.pl

1 Polish Academy of Sciences Botanical Garden - Center for Biological Diversity Conservation in Powsin, Prawdziwka 2, 02-973 Warsaw, Poland 2015b) or groups of competent cells (Choi and Soh 1995; Taylor and Vasil 1996; Choi et al. 1998; Puigderrajols et al. 2001; Corredoira et al. 2006). Although SE has been successfully achieved in numerous species of seed plants, only a few published reports describe this phenomenon in monilophytes, and all these studies were performed on the tree fern Cyathea delgadii Sternb. (Mikuła et al. 2015a, b; Domżalska et al. 2017; Grzyb et al. 2017, 2018). These investigations demonstrated that somatic embryos of $C$. delgadii are formed directly from single epidermal cells. Embryogenic cultures of ferns, that represent the closest living relatives of spermatophytes (Pryer et al. 2001), promise to be useful in the study of some fundamental problems relating to somatic embryo initiation and development (Domżalska et al. 2017; Grzyb et al. 2017, 2018). However, a better understanding of factors that control the somatic embryo origin and improve the efficiency of SE in ferns is still required.

The pathway and effectiveness of somatic embryo differentiation depends on various factors (Gaj 2004). The source 
and physiological state of the explant appears to be the main initiator of direct SE (Williams and Maheswaran 1986; Merkle et al. 1995; Choi et al. 1998). Generally, somatic embryos can be induced from a range of explants and their highly differentiated cells, such as those of the leaf (Wang and Bhalla 2004; Chung et al. 2007), root (Iantcheva et al. 2005), glandular trichomes (Kim et al. 2007) or even fully differentiated stomatal guard cells (Chen and Hong 2012). However, immature and young plant material, such as zygotic and somatic embryos, or parts of seedlings, appears to be more responsive to in vitro treatments (Williams and Maheswaran 1986; Merkle et al. 1995). Its cells require minor gene reprogramming and hence, direct SE can be readily induced from these (Merkle et al. 1995; Karami et al. 2009). The initiation of SE can occur simultaneously along unicellular and multicellular pathways on the same explant, as it was demonstrated for zygotic embryo cultures of white clover (Maheswaran and Williams 1985), pearl millet (Taylor and Vasil 1996) and pineapple guava (Canhoto and Cruz 1996; Canhoto et al. 1996). Alternatively, both pathways of SE can be induced independently of each other by using various types of initial explants (Choi et al. 1998; Maximova et al. 2002) or plant growth regulators (PGRs) (Lee et al. 1990; Choi and Soh 1995; de Almeida et al. 2012). The number of explant cells involved in somatic embryo production is important in connection with the genetic chimerism of regenerated plants. Therefore, unicellular origin of embryo may be more desirable than multicellular one. The embryogenic competence of in vitro-cultured somatic cells can also be stimulated by high osmotic pressure. This treatment has been shown to greatly enhance somatic embryo production (Kamada et al. 1993; Ikeda-Iwai et al. 2003; Karami et al. 2006; You et al. 2006; Mikuła et al. 2011a, b) and germination (Attree et al. 1991).

Somatic embryogenesis in ferns was first reported for C. delgadii as the most promising tissue culture technology to date for the large-scale clonal propagation of these plants (Mikuła et al. 2015b). In order to efficiently induce somatic embryos in this species on hormone-free medium, the role of different endogenous and exogenous factors should be investigated. Our previous work demonstrated that the source of plant material (etiolation and age of donor plants, length of initial explants), as well as physical (photoperiod, darkness) and chemical (sucrose and mineral salt concentrations in the medium) factors affected the efficiency of SE (Mikuła et al. 2015a). The basis for the induction of SE in C. delgadii is an appropriate hormonal balance in explant cells established by etiolation of donor plantlets (Grzyb et al. 2017). We also improved the current understanding of physiological and molecular processes involved in the induction and expression of early SE in this species (Grzyb et al. 2018; Domżalska et al. 2017). Our previous achievements have been summarised in the latest review article (Mikuła et al.
2018). The present paper focuses on the effect of explant type, length and diameter of explant-donor frond and stress treatment on the pathway and efficiency of SE in C. delgadii.

\section{Materials and methods}

\section{Plant material and growth conditions}

The source of plant material were somatic embryo-derived sporophytes of $C$. delgadii cultured on Murashige and Skoog's (1962) medium containing half-strength of macroand micronutrients, a full complement of vitamins (1/2 MS), and $2 \%(\mathrm{w} / \mathrm{v})$ sucrose. The medium was solidified using $0.7 \%$ plant agar (Duchefa Biochemie). The $\mathrm{pH}$ was adjusted to 5.8 before autoclaving. Stock cultures were incubated in constant darkness, in a climatic chamber at $24 \pm 1{ }^{\circ} \mathrm{C}$. For induction of SE, only first fronds of 5-month-old plantlets were used as a source of stipe and internode explants (Fig. 1). The initial cultures were maintained on $1 / 2 \mathrm{MS}$ medium supplemented with $1 \%(\mathrm{w} / \mathrm{v})$ sucrose, in constant darkness.

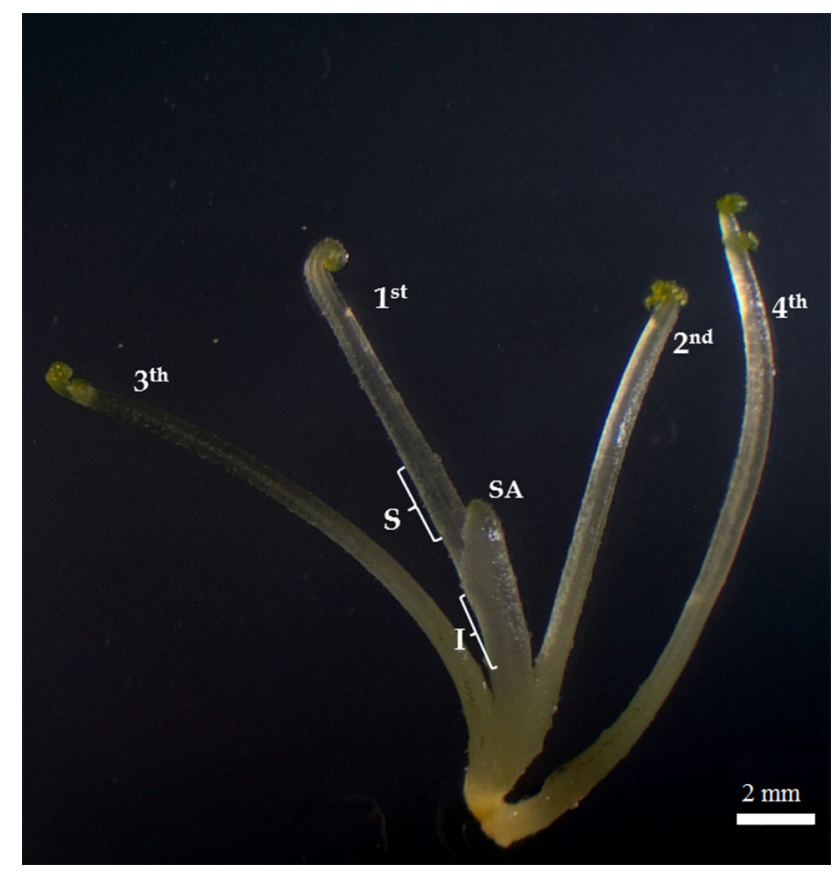

Fig. 1 Five-month-old, etiolated sporophyte of Cyathea delgadii used as a source of stipe and internode explants for culture initiation; $I$ internode explant (the part of sporophyte located below shoot apex and about $1 \mathrm{~mm}$ above basal part of the second frond), $S$ stipe explant (the part of first frond located $1 \mathrm{~mm}$ above shoot apex), $S A$ shoot apex, 1 st-4th fronds 


\section{Induction of somatic embryogenesis}

To determine whether length and diameter of the explantdonor frond affects embryogenic potential, stipe explants ( $2.5 \mathrm{~mm}$ in length) were excised from the first fronds measuring $5,10,15,20 \mathrm{~mm}$ in length, and more or less than $300 \mu \mathrm{m}$ in diameter at their base (marked as $<300$ or $>300$, respectively). In the case of internode explants, sections measuring $0.5,1.0,1.5,2.0$, and $2.5 \mathrm{~mm}$ in length were used. Their diameter was similar, regardless of length.

The effect of air desiccation on SE was tested by using a laminar flow cabinet. The stipe and internode explants were exposed to air flow for 15, 30, 45 and $60 \mathrm{~min}$. Also, the effect of sucrose on SE was examined by treating the stipe and internode explants with an aqueous solution of $0.4,0.5$, 0.6 or $0.7 \mathrm{M}$ sucrose for $15,30,45$ or $60 \mathrm{~min}$. Non-treated explants were used as the control. Sterile water, that was used as an additional control, did not affect SE. Both stress treatments were conducted in the dark, at $24 \pm 1{ }^{\circ} \mathrm{C}$. Following stress treatment, explants were maintained on $1 / 2 \mathrm{MS}$ medium supplemented with $1 \%(\mathrm{w} / \mathrm{v})$ sucrose, in constant darkness at $24 \pm 1{ }^{\circ} \mathrm{C}$.

\section{Evaluation of SE efficiency}

The efficiency of SE was calculated as the percentage of responding explants and the number of somatic embryos per responding explant following 1 month of culture for internodes, and 2 months of culture for stipes. The somatic embryo production capacity index (SEPCI) was calculated by multiplying the percentage of responding explants by the number of somatic embryos formed per explant and then dividing the result by 100 . In order to evaluate the embryogenic potential of stipe and internode explants, 60 explants for each experiment were examined, and each experiment was repeated three times.

\section{Microscopic examination}

The visualisation of SE on the stipe and internode explants was made using an environmental scanning electron microscope (ESEM; FEI QUANTA 200; $0.75 \mathrm{Tr}$, at a relative humidity of up to $100 \%$, and reduced pressure of less than $\left.10^{-4} \mathrm{~Pa}\right)$.

The explants were also fixed in $2.5 \%$ paraformaldehyde (Fluka, Buchs, Switzerland) and 2.5\% glutaraldehyde (Sigma, St. Louis, USA) in $0.05 \mathrm{M}$ sodium cacodylate buffer (Fluka) ( $\mathrm{pH} 7.2$; room temperature; $24 \mathrm{~h}$ ) for microscopic analysis. After rinsing in $0.05 \mathrm{M}$ cacodylic buffer, the samples were post-fixed in $2 \%$ osmium tetroxide (Carl Roth, Karlsruhe, Germany) in $0.05 \mathrm{M}$ cacodylate buffer at $4{ }^{\circ} \mathrm{C}$ for $6 \mathrm{~h}$. Then the explants were dehydrated in a graded ethanol series $(30,50,70,90,96 \%)$ for $2 \mathrm{~h}$ in each concentration, followed by absolute ethanol and propylene oxide. The samples were infiltrated in a graded Epon epoxy resin (Sigma) mixtures for $48 \mathrm{~h}$ in total and transferred into flat embedding molds; the resin polymerised at $65^{\circ} \mathrm{C}$ for $16 \mathrm{~h}$. Semi-thin sections $(2 \mu \mathrm{m})$ were cut using a Leica Ultracut $\mathrm{E}$ ultramicrotome (Leica, Wetzlar, Germany) and stained with $0.1 \%$ toluidine blue in $1 \%$ borax for $15 \mathrm{~min}$. They were examined using a Vanox light microscope (Olympus, Japan) with a computer image analysis system (cellSens Standard ver. 1.7).

\section{Statistical analysis}

Statistical analyses were performed using Statgraphics Plus software. Results were expressed as the mean \pm SD. The one- or two-way ANOVA analysis of variance and Fisher's least significant difference (LSD) procedure were used. Significance was set at the 0.05 level.

\section{Results}

\section{Effect of explant type on embryogenic pathway}

Depending upon the explant used for culture initiation, the uni- or multi-cellular type of the embryogenic pathway was observed (Fig. 2). Somatic embryos of single cell origin developed on stipe explants (Fig. 2a-d), whereas on internode explants, the embryos arose from groups of neighbouring cells (Fig. 2e-h).

A short period was required for the expression of SE and somatic embryo formation. The epidermal cells of the stipe began to divide from day 8 of culture (Fig. 2a). Several cell divisions perpendicular to the stipe axis (Fig. 2b) led to the development of numerous somatic embryos at linear stage (Figs. 2c, 3a, b). With increasing frequency of cell divisions occurring within the embryo body, its structure changed from linear to spatial (Fig. 2d). These structures were able to develop a complete functional embryo (Fig. 3c). Neither proliferation of other cells (including the epidermis, cortex and vascular bundle), nor their expansion, or the formation of a meristematic layer or callus, were observed on the surface of stipe explants (Fig. 2c, d) as well as inside it (Fig. 3a, b).

The cells of internodes began to divide at about day 4 of explant culture on the induction medium (Fig. 2e). These divisions increased over time, and after 6 days of culture, many cells of the epidermis were seen to divide on the surface of the explant (Fig. 2f). Together with epidermis, the multiple-divided cortical cells formed a proliferation zone that was composed of several layers of cells with meristematic features, such as small size and isodiametric shape (Fig. 3d, e). Four days later, it was possible to observe somatic embryos of multicellular origin (Figs. 2g, 3f) whose leaf primordia had begun to split at the tip (Fig. 2g, 
Fig. 2 Pathways of somatic embryo differentiation in stipe (a-d) and internode (e-h) explants during 21 and 15 days of culture, respectively. Culture conditions: $1 / 2 \mathrm{MS}$, $1 \%$ sucrose, constant darkness. a First cell division of stipe epidermis; b pro-embryos following several cell divisions perpendicular to the stipe axis; c several somatic embryos at linear developmental stage; $\mathbf{d}$ somatic embryos of single cell origin at early embryonic leaf stage; $\mathbf{e}$ first cell divisions of the internode epidermis and enlarged image of proliferation zone (inset). Epidermal cells following one or two cell divisions perpendicular to the axis of the internode. Arrows show cell walls; f proliferation zone formed by numerous dividing cells with meristematic features, i.e. small size and isodiametric shape; $\mathbf{g}$ somatic embryos of multicellular origin bearing leaf primordia; $\mathbf{h}$ somatic embryos of multicellular origin in contact with the basal area are typically fused to the original explant tissue. Following 15 days of culture, they have fully developed leaf primordia that are protected by numerous trichomes. Asterisk somatic embryo, $L P$ leaf primordium, $N P Z$ non-proliferation zone, $P Z$ proliferation zone, Se somatic embryo, $\operatorname{Tr}$ trichome

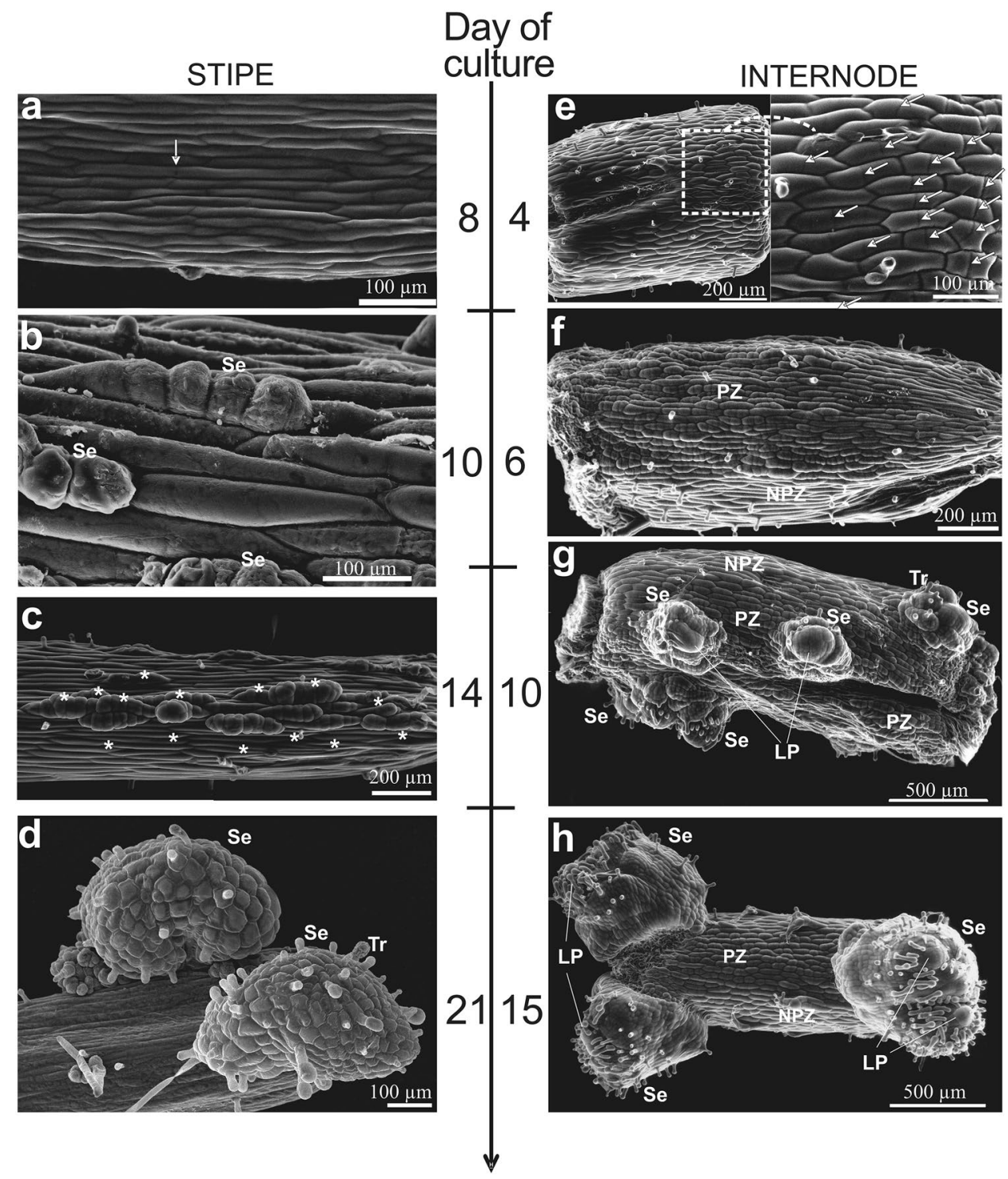

h). No vascular connection between somatic embryos and explants was observed (Fig. 3d-f). Development of early multicellular embryos into well differentiated somatic embryos was quick and synchronous (Figs. $2 \mathrm{~h}, 3 \mathrm{~g}, \mathrm{~h}$ ). They had a high capacity for embryonic root formation (Fig. 3h, i). Numerous trichomes were observed on the surface of the embryo body. They were mostly located near leaf primordia (Figs. 2d, h, 3c, g, h).

Somatic embryos originating from internode explants grew much faster than those formed on stipes. In the early stages of development, the somatic embryos were welldefined and presented a typical early embryogenic leaf stage of development in both explant types (Fig. 3c, g, h). Both paths of somatic embryo initiation led to production of complete plantlets without sign of morphological disturbances.

\section{Effect of length and diameter of explant-donor frond on the SE efficiency}

The efficiency of SE was dependent on the length and diameter of the first frond used as the source of stipe explants (Table 1). The greatest percentage of explants capable of SE (about 90\%) was obtained from fronds measuring $<300 \mu \mathrm{m}$ in diameter, and 10 or $15 \mathrm{~mm}$ in length. The greatest number of somatic embryos was also obtained for these explants (21.4 or 17.9, respectively). Explants collected from fronds measuring $>300 \mu \mathrm{m}$ in diameter, regardless of length, were characterised by low SE efficiency. The percentage of responding explants was no greater than $34.2 \%$, and the number of somatic embryos per responding explant was no more than 17.1. The value of the SEPCI index was at least threefold greater in fronds 

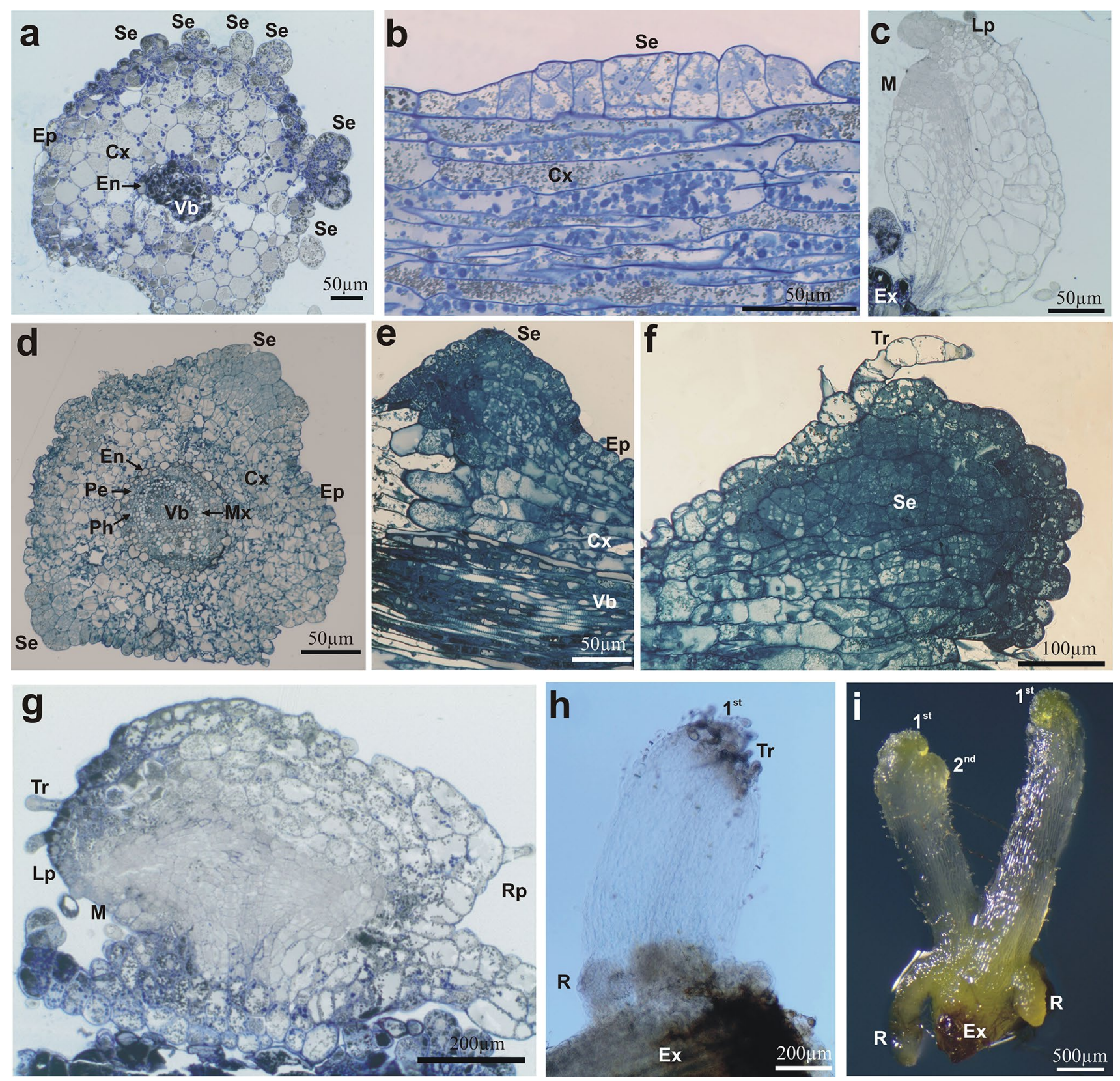

Fig. 3 Morphological evidences for uni- $(\mathbf{a}-\mathbf{c})$ and multicellular $(\mathbf{d}-\mathbf{i})$ origin of somatic embryos in Cyathea delgadii. a Transverse section of a stipe explant showing divided cells of epidermis that formed somatic embryos, 14th day of culture; b longitudinal section of a stipe explant showing linear embryo originating from a single cell of epidermis, 14th day of culture; c single cell-origin somatic embryo at early embryonic leaf stage; $\mathbf{d}$ the multiple-divided epidermal and cortical cells of internode explant (transverse section); 6th day of culture; e meristematic primordium emerging on internode explant (longitudinal section); 6th day of culture; $\mathbf{f}$ embryonic structure formed from cells of the epidermal and cortical layers of internode explant; 10th day of culture (longitudinal section); $\mathbf{g}$ well differentiated somatic

embryo of multicellular origin showing meristematic zone; $\mathbf{h}$ elongation of embryo body. Presence of trichomes indicates the proximity of developing meristem (cleared in methyl salicilate according to Mikuła et al. 2015b); i somatic embryo-derived sporophytes showing the leaf primordia and roots. Semi-thin section of stipe (a, b) and internode (d-f) explants, and somatic embryos (c, g) stained with toluidine blue. Cultures were maintained in constant darkness. $C x$ cortex, En endodermis, Ep epidermis, Ex explant, $L p$ first leaf primordium, $M$ shoot apical meristem, $M x$ metaxylem, $P e$ pericycle, $P h$ phloem, $R$ root, $R p$ root pole, $S e$ somatic embryo, $T r$ trichome, $V b$ vascular bundle, 1 st first leaf, $2 n d$ second leaf 
Table 1 Embryogenic capacity of $C$. delgadii stipe explants taken from the first fronds differing in length and diameter

\begin{tabular}{llllr}
\hline $\begin{array}{l}\text { Basal diameter of the } \\
\text { first frond }(\mu \mathrm{m})\end{array}$ & $\begin{array}{l}\text { Length of the first } \\
\text { frond }(\mathrm{mm})\end{array}$ & $\begin{array}{l}\text { \% of responding } \\
\text { explants }\end{array}$ & $\begin{array}{l}\text { No. somatic embryos/ } \\
\text { responding explant }\end{array}$ & SEPCI \\
\hline$>300$ & 5 & $25.8 \pm 4.7 \mathrm{~d}$ & $13.0 \pm 1.1 \mathrm{c}$ & 3.4 \\
& 10 & $34.2 \pm 6.6 \mathrm{c}$ & $17.1 \pm 3.6 \mathrm{~b}$ & 5.8 \\
& 15 & $23.3 \pm 5.3 \mathrm{~d}$ & $15.5 \pm 2.6 \mathrm{bc}$ & 3.6 \\
& 20 & $11.7 \pm 3.8 \mathrm{e}$ & $6.9 \pm 2.3 \mathrm{~d}$ & 0.8 \\
$<300$ & 5 & $51.2 \pm 11.0 \mathrm{~b}$ & $16.9 \pm 2.3 \mathrm{~b}$ & 8.7 \\
& 10 & $91.7 \pm 6.2 \mathrm{a}$ & $21.4 \pm 4.8 \mathrm{a}$ & 19.6 \\
& 15 & $88.7 \pm 6.8 \mathrm{a}$ & $17.9 \pm 2.3 \mathrm{~b}$ & 15.9 \\
& 20 & $61.7 \pm 4.5 \mathrm{~b}$ & $11.4 \pm 4.8 \mathrm{c}$ & 7.0 \\
\hline
\end{tabular}

SE efficiency was assessed after 2 months of culture in darkness

SEPCI somatic embryo production capacity index, $\pm \mathrm{SD}$
Table 2 Effect of internode explant length on the efficiency of SE in C. delgadii after 1 month of culture in darkness

\begin{tabular}{llll}
\hline $\begin{array}{l}\text { Length of the } \\
\text { internode explants } \\
(\mathrm{mm})\end{array}$ & $\begin{array}{l}\text { \% of } \\
\text { responding } \\
\text { explants }\end{array}$ & $\begin{array}{l}\text { No. of somatic } \\
\text { embryos/responding } \\
\text { explants }\end{array}$ & SEPCI \\
\hline 0.5 & $95.8 \pm 3.7 \mathrm{a}$ & $2.0 \pm 1.0 \mathrm{~b}$ & 2.0 \\
1.0 & $94.2 \pm 6.2 \mathrm{a}$ & $2.5 \pm 0.6 \mathrm{a}$ & 2.4 \\
1.5 & $93.3 \pm 1.3 \mathrm{a}$ & $3.1 \pm 1.1 \mathrm{a}$ & 2.9 \\
2.0 & $91.7 \pm 3.1 \mathrm{a}$ & $2.9 \pm 0.3 \mathrm{a}$ & 2.7 \\
2.5 & $91.2 \pm 1.9 \mathrm{a}$ & $2.9 \pm 0.5 \mathrm{a}$ & 2.6 \\
\hline
\end{tabular}

SEPCI somatic embryo production capacity index, $\pm \mathrm{SD}$

measuring $<300 \mu \mathrm{m}$ than in those measuring $>300 \mu \mathrm{m}$ in diameter.

The efficiency of SE did not depend on the length of internode between the first and second frond used as the source of explants (Table 2). The percentage of responding explants in all cases exceeded $91 \%$. A reduced number of somatic embryos (2) and the lowest SEPCI index (2.0) were observed only for the shortest $(0.5 \mathrm{~mm})$ internodes. The highest SEPCI index (2.9) was obtained for internode explants measuring $1.5 \mathrm{~mm}$.

\section{Effect of stress treatment on the embryogenic pathway and SE efficiency}

To improve the efficiency of SE in $C$. delgadii, the effect of stress treatment was assessed. When stipe explants were subjected to air desiccation for 15-60 min, their capacity to produce somatic embryos became highly suppressed (Table 3). In internode explants, the SE efficiency increased from about three to four somatic embryos following $1 \mathrm{~h}$ of air desiccation.

The efficiency of somatic embryo formation was dependent on the explant type, as well as on the concentration and
Table 3 Effect of air desiccation on the efficiency of SE in C. delgadii

\begin{tabular}{lccc}
\hline $\begin{array}{l}\text { Time of air des- } \\
\text { iccation (min) }\end{array}$ & $\begin{array}{l}\text { \% of respond- } \\
\text { ing explants }\end{array}$ & $\begin{array}{l}\text { No. of somatic embryos/ } \\
\text { responding explants }\end{array}$ & SEPCI \\
\hline Stipe explant & & & \\
0 & $86.7 \pm 8.6 \mathrm{a}$ & $18.2 \pm 6.9 \mathrm{a}$ & 15.8 \\
15 & $35.0 \pm 10.8 \mathrm{c}$ & $13.5 \pm 6.4 \mathrm{~b}$ & 4.7 \\
30 & $26.7 \pm 12.5 \mathrm{c}$ & $4.8 \pm 1.1 \mathrm{c}$ & 1.3 \\
45 & $58.3 \pm 16.5 \mathrm{~b}$ & $5.5 \pm 1.6 \mathrm{c}$ & 3.2 \\
60 & $50.0 \pm 20.4 \mathrm{~b}$ & $10.0 \pm 2.6 \mathrm{~b}$ & 5.0 \\
Internode explant & & & \\
0 & $98.3 \pm 2.4 \mathrm{~b}$ & $2.9 \pm 0.4 \mathrm{c}$ & 2.9 \\
15 & $100 \pm 0.0 \mathrm{a}$ & $3.7 \pm 0.6 \mathrm{~b}$ & 3.7 \\
30 & $100 \pm 0.0 \mathrm{a}$ & $3.6 \pm 0.5 \mathrm{~b}$ & 3.6 \\
45 & $100 \pm 0.0 \mathrm{a}$ & $3.8 \pm 0.1 \mathrm{~b}$ & 3.8 \\
60 & $100 \pm 0.0 \mathrm{a}$ & $4.3 \pm 0.4 \mathrm{a}$ & 4.3 \\
\hline
\end{tabular}

Data were collected after 1 month of culture

Different letters differ significantly at $\mathrm{p} \leq 0.05$ according to one-way ANOVA analysis of variance and Fisher's least significant difference (LSD) test

SEPCI somatic embryo production capacity index, $\pm \mathrm{SD}$

duration of sucrose treatment (Table 4). When internode explants were treated with $0.4 \mathrm{M}$ sucrose for $45 \mathrm{~min}$, more than a fourfold increase in the number of somatic embryos was obtained. The percentage of explants producing somatic embryos compared to that of non-treated internodes was significantly lower. By raising the concentration of sucrose and subjecting explants to a longer period of stress treatment, the SE efficiency became reduced. When stipe explants were used in these experiments, they failed to produce somatic embryos for any of the sucrose concentrations used (Table 4).

The microscopic analysis revealed that somatic embryo formation on the surface of internode explants treated with sucrose solutions occurs in a distinctive manner (Fig. 4). 
Table 4 Effect of sucrose treatment on SE efficiency in C. delgadii

\begin{tabular}{|c|c|c|c|c|c|c|}
\hline \multicolumn{2}{|c|}{ Sucrose treatment } & \multicolumn{2}{|c|}{$\%$ of responding explants } & \multicolumn{2}{|c|}{$\begin{array}{l}\text { No. of somatic embryos/responding } \\
\text { explants }\end{array}$} & \multirow{2}{*}{$\begin{array}{l}\text { SEPCI } \\
\text { I }\end{array}$} \\
\hline $\begin{array}{l}\text { Concentration } \\
\text { (M) }\end{array}$ & $\begin{array}{l}\text { Duration } \\
\text { (min) }\end{array}$ & I & $\mathrm{S}$ & I & $\mathrm{S}$ & \\
\hline 0 & 0 & $98.3 \pm 2.4 \mathrm{a}$ & $91.7 \pm 6.2 \mathrm{a}$ & $2.9 \pm 0.4 \mathrm{e}$ & $21.4 \pm 4.8 \mathrm{a}$ & 2.9 \\
\hline \multirow[t]{4}{*}{0.4} & 15 & $95 \pm 1.1 \mathrm{ab}$ & ob & $9.3 \pm 0.9 b$ & ob & 8.9 \\
\hline & 30 & $95 \pm 1.6 \mathrm{ab}$ & Ob & $6.5 \pm 0.8 \mathrm{~d}$ & $0 \mathrm{~b}$ & 6.2 \\
\hline & 45 & $90 \pm 2.6 b$ & Ob & $12.1 \pm 2.1 b$ & Ob & 10.9 \\
\hline & 60 & $72.5 \pm 2.1 \mathrm{c}$ & $0 \mathrm{~b}$ & $16.6 \pm 1.2 \mathrm{a}$ & $0 \mathrm{~b}$ & 12 \\
\hline \multirow[t]{4}{*}{0.5} & 15 & $100 \pm 2.4 \mathrm{a}$ & Ob & $5.9 \pm 1.1 \mathrm{~d}$ & Ob & 5.9 \\
\hline & 30 & $70 \pm 1.9 \mathrm{c}$ & Ob & $13.7 \pm 1.6 b$ & Ob & 9.6 \\
\hline & 45 & $20 \pm 3.1 \mathrm{~d}$ & $0 \mathrm{~b}$ & $19 \pm 1.1 \mathrm{e}$ & $0 \mathrm{~b}$ & 3.8 \\
\hline & 60 & $5 \pm 1.1 \mathrm{e}$ & ob & $12 \pm 0.1$ & $0 b$ & 0.6 \\
\hline \multirow[t]{4}{*}{0.6} & 15 & $90 \pm 3.3 b$ & $0 \mathrm{~b}$ & $8.5 \pm 1.8 \mathrm{c}$ & $0 \mathrm{~b}$ & 7.7 \\
\hline & 30 & $20 \pm 2.5 \mathrm{~d}$ & $0 \mathrm{~b}$ & $2.9 \pm 1.3 \mathrm{e}$ & Ob & 0.6 \\
\hline & 45 & Of & ob & Of & ob & 0 \\
\hline & 60 & Of & $0 \mathrm{~b}$ & Of & $0 \mathrm{~b}$ & 0 \\
\hline \multirow[t]{4}{*}{0.7} & 15 & $90 \pm 2.6 b$ & Ob & $10.3 \pm 1.1 b$ & Ob & 9.25 \\
\hline & 30 & $15 \pm 2.2 \mathrm{~d}$ & $0 \mathrm{~b}$ & $16 \pm 0.4 \mathrm{e}$ & ob & 0.4 \\
\hline & 45 & Of & Ob & Of & Ob & 0 \\
\hline & 60 & Of & Ob & Of & Ob & 0 \\
\hline
\end{tabular}

Data were collected after 1 month of culture

Different letters differ significantly at $\mathrm{p} \leq 0.05$ according to two-way ANOVA analysis of variance and Fisher's least significant difference (LSD) test

$S E P C I$ somatic embryo production capacity index, $I$ internode explant, $S$ stipe explant, \pm SD
As a results of this treatment, somatic embryos of single cell origin developed near structures of multicellular origin (Fig. 4a, b). There was an obvious reduction in the number of somatic embryos of multicellular origin in response to the duration of sucrose treatment. Consequently, only the unicellular pathway of embryo formation was observed when internode explants were treated with sucrose for longer than $30 \mathrm{~min}$ (Fig. 4c). Subsequently, both types of structures developed into mature embryos, thereby increasing the yield of this process (Fig. 4d).

\section{Discussion}

The pathway and the onset of SE are determined by the physiological and morphological maturity of the plant material source from which the explant derived (Gaj 2004). Initiation of direct $\mathrm{SE}$ is restricted to certain responsive cells (Quiroz-Figueroa et al. 2002). According to Williams and Maheswaran (1986), single initials are characteristic of older plant material in which only some epidermal cells are still immature. These cells remain in the predetermined embryogenic condition. The multiple-cell initiation of SE is thought to be a consequence of the explant containing several neighbouring cells in the embryogenic state (Puigderrajols et al. 2001). In our studies, we provide for the first time the structural evidence for the multicellular origin of somatic embryos in fern. We demonstrated that the somatic embryos of $C$. delgadii may develop not only from single epidermal cells, but also from clusters of rapidly dividing cells of epidermis and cortex. The pathway of embryo differentiation was closely related to the explant type used for culture initiation. Somatic embryos derived from stipes of in vitro-grown sporophytes followed a unicellular pathway of direct SE, whereas those derived from internodes followed a multicellular pathway. We also showed that both the activation of cell divisions and the formation of somatic embryos occurred earlier in the culture of internodes than in that of stipe explants. Such behaviour may be a consequence of the different degree of cell maturity of these explants and different content of endogenous hormones (Michalczuk et al. 1992; Centeno et al. 1996; Grzyb et al. 2017). In C. delgadii, high frequency of cell divisions in the epidermal and cortical layers of internode explants, and the capability of many neighbouring cells to act in a coordinated manner led to the differentiation and rapid embryo development. We speculate that this may be the main reason why somatic embryo formation via the multicellular pathway occurs very quickly.

Although both investigated explant types of $C$. delgadii were able to produce somatic embryos, the morphogenic capacity of internodes was much lower than stipes. Almost $92 \%$ of stipe explants excised from the first frond, measuring 
Fig. 4 Modification by sucrose treatment of pathways of somatic embryogenesis on internode explants of Cyathea delgadii (scanning electron micrographs). a Somatic embryos that have developed along unicellular and multicellular pathways following treatment with $0.4 \mathrm{M}$ sucrose for 30 min after 12 days of culture and $\mathbf{b} 20$ days of culture. c Numerous somatic embryos that have developed along the unicellular pathway following the treatment of internode explants with $0.5 \mathrm{M}$ sucrose for $45 \mathrm{~min}$ (day 12 of culture). d Numerous somatic embryoderived sporophytes obtained from internode explants treated with $0.4 \mathrm{M}$ sucrose for $30 \mathrm{~min}$ after 30 days of culture. Mse multicellular origin of somatic embryo, Sse single cell origin of somatic embryo, 1 juvenile sporophyte derived from a single epidermal cell; 2 juvenile sporophyte derived from several explant cells
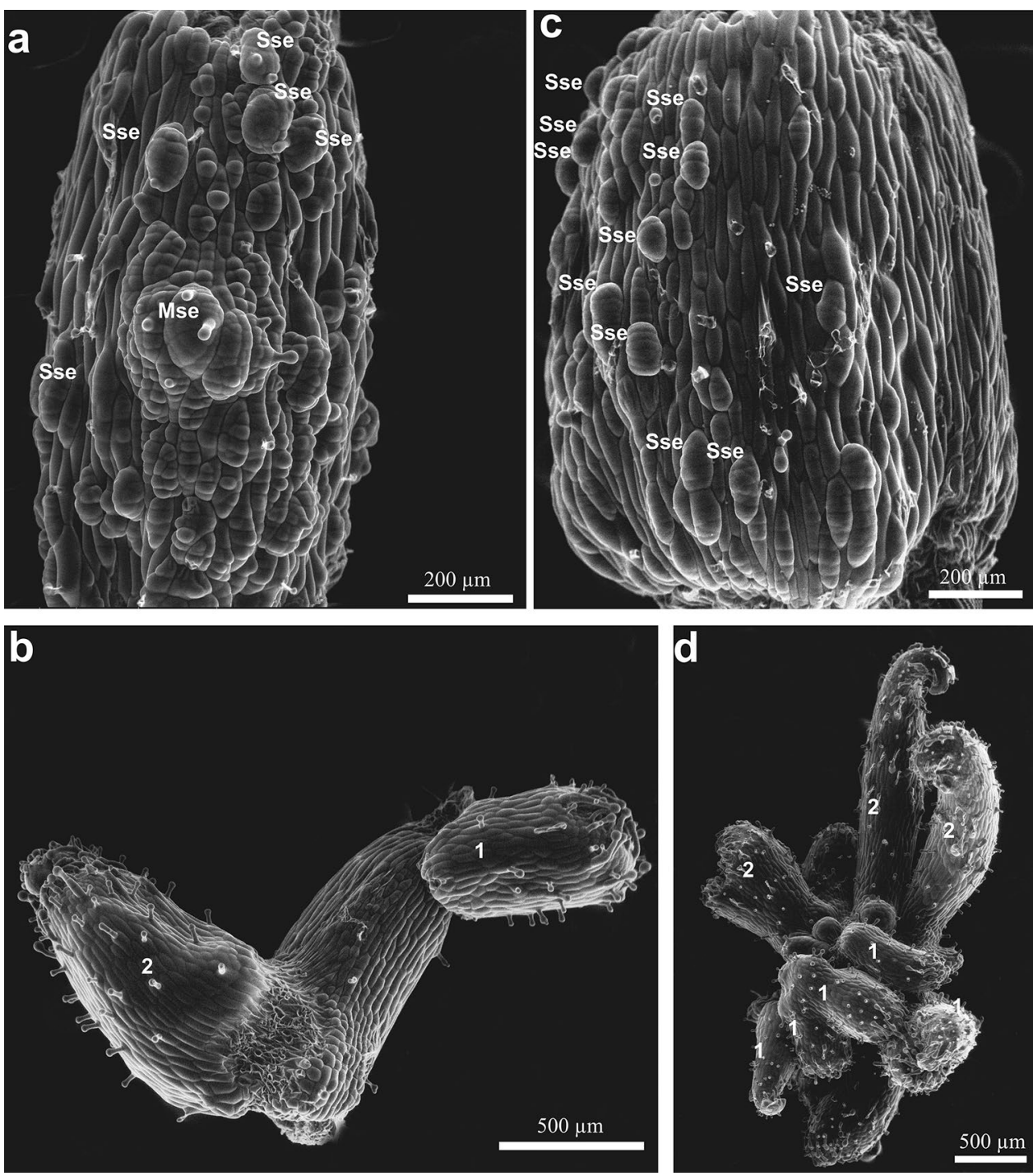

$10 \mathrm{~mm}$ in length and less than $300 \mu \mathrm{m}$ in diameter, produced, on average, 21 somatic embryos. As a result of frequent cell divisions, the groups of embryogenic-competent cells of internode explants formed protuberances that gave rise to a maximum of three somatic embryos. Similarly, a lower percentage of explants producing somatic embryos was observed for multicellular SE than for unicellular SE in Theobroma cacao L. (Maximova et al. 2002). However, in this species, the difference in SE efficiency was due to severe embryonic malformations that led to the formation of abnormal somatic embryos or embryo-like structures. In the absence of abnormalities during the development of somatic embryos in $C$. delgadii, it would appear that the competition may have prevented further development of some embryogenic cells in favour of others, as was proposed by Jones and Rost (1989).

In $C$. delgadii, beside the environmental factors (such as the mineral and organic nutrients of culture medium, or light), some explant features can affect the efficiency of SE (Mikuła et al. 2015a). The key factor to induction of the embryogenic capacity is the etiolation of fern sporophytes that are the source of plant material (Mikuła et al. 2015a). Our previous studies also showed that SE induced on stipes can be effectively stimulated by the length of explants (Mikuła et al. 2015a), however, the factor is ineffective in the case of internode explants. In this study, the donor fronds differing in their length and diameter were found to have a profound influence on SE of $C$. delgadii. Short and thin fronds were found to be more effective in the production of somatic embryos, and it may be related to their age. The positive effect of immature tissues or relatively young individuals on $\mathrm{SE}$ as described here is consistent with the earlier observations made with Trifolium repens (Maheswaran and Williams 1985) or Eucalyptus camaldulensis (Prakash and Gurumurthi 2010). 
Induction of SE on the internode explants of $C$. delgadii can be a good example of stress-related plant response. We revealed that stress treatment can alter the pathway of somatic embryo differentiation and affect embryogenic capacity. The SE efficiency of internode explants was significantly improved by short-term treatment (up to $1 \mathrm{~h}$ ) with sucrose. There is evidence in the literature to support the hypothesis that osmotic treatment may enhance somatic embryo production in two ways: it may cause selection of certain cell types, as shown for osmotically dehydrated embryogenic tissue of Gentiana cruciata, G. kurroo (Mikuła et al. 2011a, b) and Pinus sylvestris (Häggman et al. 1998), or alternatively, severe but non-fatal stress treatment may lead to the symplasmic isolation of cells (Marzec and Kurczynska 2014). It was demonstrated that disruption of plasmodesmata between explant cells promotes the somatic-toembryogenic transition (Verdeil et al. 2001; You et al. 2006). In $C$. delgadii, changing the pathway of the origin of somatic embryos from multicellular to unicellular supports the view that the acquisition of embryogenic competence is preceded by cell isolation in sucrose-treated internode explants. This treatment has enabled the establishment of a new tissue culture method for inducing efficient SE in $C$. delgadii.

In summary, the results presented in this paper together with earlier studies (Mikuła et al. 2015a) help to broaden our knowledge of factors influencing efficiency of SE in monilophytes. They also allow us to trace the pathway of somatic embryo origin that is determined by the explant type and short-term sucrose treatment. This stress treatment improves the efficiency of direct SE by replacing the multicellular origin of somatic embryos with unicellular pathway. These findings open new possibilities for studying mechanisms of expression of embryogenic totipotency associated with a single- and multiple-cell origin of somatic embryos, especially since both pathways occur via direct SE without involving intermediate callus, on hormone-free medium.

Acknowledgements The authors thank Dr. Mirosław Sobczak (Warsaw University of Life Sciences-SGGW, Poland) for his help during microscopic analysis, and Professor Jan J. Rybczyński (PAS Botanical Garden - CBDC in Powsin, Warsaw, Poland) for valuable advices and creative discussion during preparation of the manuscript. This research was supported by the Polish National Science Centre (NCN), No. $2017 / 27 /$ N/NZ3/00434.

Author contributions $\mathrm{MG}$ and AM conceived and designed the experiments, wrote the paper. MG performed the experiments and analysed the data.

\section{Compliance with ethical standards}

Conflict of interest The authors declare that they have no conflict of interest.
Open Access This article is distributed under the terms of the Creative Commons Attribution 4.0 International License (http://creativeco mmons.org/licenses/by/4.0/), which permits unrestricted use, distribution, and reproduction in any medium, provided you give appropriate credit to the original author(s) and the source, provide a link to the Creative Commons license, and indicate if changes were made.

\section{References}

Attree SM, Moore D, Sawhney VK, Fowke LC (1991) Enhanced maturation and desiccation tolerance of white spruce [Picea glauca (Moench) Voss] somatic embryos: effects of a non-plasmolysing water stress and abscisic acid. Ann Bot 68:519-525. https://doi. org/10.1093/oxfordjournals.aob.a088291

Canhoto JM, Cruz GS (1996) Histodifferentiation of somatic embryos in cotyledons of pineapple guava (Feijoa sellowiana Berg). Protoplasma 191:34-45. https://doi.org/10.1007/BF01280823

Canhoto JM, Mesquita JF, Cruz GS (1996) Ultrastructural changes in cotyledons of pineapple guava (Myrtaceae) during somatic embryogenesis. Ann Bot 78:513-521. https://doi.org/10.1006/ anbo.1996.0149

Centeno ML, Rodríguez A, Feito I, Fernández B (1996) Relationship between endogenous auxin and cytokinin levels and morphogenic responses in Actinidia deliciosa tissue cultures. Plant Cell Rep 16:58-62. https://doi.org/10.1007/BF01275450

Chen JT, Hong PI (2012) Cellular origin and development of secondary somatic embryos in Oncidium leaf cultures. Biol Plant 56:215220. https://doi.org/10.1007/s10535-012-0054-x

Choi YE, Soh WY (1995) Origin of somatic embryos from excised cotyledons of ginseng. Korean J Plant Tissue Cult 22:157-163

Choi YE, Yang DC, Park JC, Soh WY, Choi KT (1998) Regenerative ability of somatic single and multiple embryos arising directly from cotyledons of Panax ginseng. Plant Cell Rep 17:544-551

Chung H-H, Chen J-T, Chang WC (2007) Plant regeneration through direct somatic embryogenesis from leaf explants of Dendrobium. Biol Plant 51:346-350. https://doi.org/10.1007/s1053 5-016-0669-4

Corredoira E, Valladares S, Vieitez AM (2006) Morphohistological analysis of the origin and development of somatic embryos from leaves of mature Quercus robur. In Vitro Cell Dev Biol Plant 42:525-533. https://doi.org/10.1079/IVP2006827

de Almeida M, de Almeida CV, Mendes Graner E, Ebling Brondani G, de Abreu-Tarazi MF (2012) Pre-procambial cells are niches for pluripotent and totipotent stem-like cells for organogenesis and somatic embryogenesis in the peach palm: a histological study. Plant Cell Rep 31:1495-1515. https://doi.org/10.1007/s0029 9-012-1264-6

Domżalska L, Kędracka-Krok S, Jankowska U, Grzyb M, Sobczak M, Rybczyński JJ, Mikuła A (2017) Proteomic analysis of stipe explants reveals differentially expressed proteins involved in early direct somatic embryogenesis of the tree fern Cyathea delgadii Sternb. Plant Sci 258:61-76. https://doi.org/10.1016/j.plant sci.2017.01.017

Gaj MD (2004) Factors influencing somatic embryogenesis induction and plant regeneration with particular reference to Arabidopsis thaliana (L.) Heynh. Plant Growth Regul 43:27-47. https://doi. org/10.1023/B:GROW.0000038275.29262.fb

Grzyb M, Kalandyk A, Waligórski P, Mikuła A (2017) The content of endogenous hormones an sugars in the process of early somatic embryogenesis in the tree fern Cyathea delgadii Sternb. Plant Cell Tissue Org Cult 129:387-397. https://doi.org/10.1007/s1124 0-017-1185-8

Grzyb M, Kalandyk A, Mikuła A (2018) Effect of TIBA, fluridone and salicylic acid on somatic embryogenesis and endogenous hormone 
and sugar contents in the tree fern Cyathea delgadii Sternb. Acta Physiol Plant 40:1. https://doi.org/10.1007/s11738-017-2577-4

Häggman HM, Ryynänen L, Aronen T, Krajnakowa J (1998) Cryopreservation of embryogenic cultures of Scots pine. Plant Cell Tissue Org Cult 54:45-53

Iantcheva A, Slavov S, Prinsen E, Vlahova M, van Onckelen H, Atanassov A (2005) Embryo induction and regeneration from root explants of Medicago truncatula after osmotic pre-treatment. Plant Cell Tissue Organ Cult 81:37-43. https://doi.org/10.1007/ s11240-004-2774-x

Ikeda-Iwai M, Umehara M, Satoh S, Kamada H (2003) Stress-induced somatic embryogenesis in vegetative tissues of Arabidopsis thaliana. Plant J 34:107-114. https://doi.org/10.1046/j.1365313X.2003.01702.X

Jones TJ, Rost TL (1989) The developmental anatomy and ultrastructure of somatic embryos from rice (Oryza sativa L.) scutellum epithelial cells. Bot Gazette 150:41-49. https://doi. org/10.1086/337746

Kamada H, Ishikawa K, Saga H, Harada H (1993) Induction of somatic embryogenesis in carrot by osmotic stress. Plant Cell Cult Lett 10:38-44. https://doi.org/10.5511/plantbiotechnology1984.10.38

Karami O, Deljou A, Esna-Ashari M, Ostad-Ahmadi P (2006) Effect of sucrose concentrations on somatic embryogenesis in carnation (Dianthus caryophyllus L.). Sci Hortic 110:340344. https://doi. org/10.1016/j.scienta.2006.07.029

Karami O, Aghavaisi B, Mahmoudi Pour A (2009) Molecular aspects of somatic-to-embryogenic transition in plants. J Chem Biol 2:177-190. https://doi.org/10.1007/s12154-009-0028-4

Kim TD, Lee BS, Kim TS, Choi YE (2007) Developmental plasticity of glandular trichomes into somatic embryogenesis in Tilia amurensis. Ann Bot 100:177-183. https://doi.org/10.1093/aob/mcm094

Lee HS, Liu JR, Yang SG, Lee YH (1990) In vitro flowering of plantlets regenerated from zygotic embryo-derived somatic embryos of ginseng. Hort Sci 25:1652-1654

Maheswaran G, Williams EG (1985) Origin and development of somatic embryoids formed directly on immature embryos of Trifolium repens in vitro. Ann Bot 56:619-630. https://doi. org/10.1093/oxfordjournals.aob.a087052

Marzec M, Kurczynska E (2014) Importance of symplasmic communication in cell differentiation. Plant Signal Behav 9:1-9. https:// doi.org/10.4161/psb.27931

Maximova SN, Alemanno L, Young A, Ferriere N, Traore A, Guiltinan MJ (2002) Efficiency, genotypic variability, and cellular origin of primary and secondary somatic embryogenesis of Theobroma cacao L. Vitro Cell Dev Biol Plant 38:252-259. https://doi. org/10.1079/IVP2001257

Merkle SA, Parrot WA, Flinn BS (1995) Morphogenic aspects of somatic embryogenesis. In: Thorpe TA (ed) Vitro embryogenesis in plants. Kluwer Academic Publishers, Dordrecht, pp 155-203. https://doi.org/10.1007/978-94-011-0485-2_5

Michalczuk L, Cooke TJ, Cohen JD (1992) Auxin levels at different stages of carrot somatic embryogenesis. Phytochemistry 31:10971103. https://doi.org/10.1016/0031-9422(92)80241-6

Mikuła A, Tomiczak K, Rybczyński JJ (2011a) Cryopreservation enhances embryogenic capacity of Gentiana cruciata (L.) suspension culture and maintains (epi)genetic uniformity of regenerants. Plant Cell Rep 30:565-574. https://doi.org/10.1007/s0029 9-010-0970-1
Mikuła A, Tomiczak K, Wójcik A, Rybczyński JJ (2011b) Encapsulation-dehydration method elevates embryogenic abilities of Gentiana kurroo cell suspension and carrying on genetic stability of its regenerants after cryopreservation. Acta Hort 908:143-154. https ://doi.org/10.17660/ActaHortic.2011.908.16

Mikuła A, Pożoga M, Grzyb M, Rybczyński JJ (2015a) An unique system of somatic embryogenesis in the tree fern Cyathea delgadii Sternb.: the importance of explant type, and physical and chemical factors. Plant Cell Tissue Organ Cult 123:467-478. https://doi. org/10.1007/s11240-015-0850-z

Mikuła A, Pożoga M, Tomiczak K, Rybczyński JJ (2015b) Somatic embryogenesis in ferns: a new experimental system. Plant Cell Rep 34:783-794. https://doi.org/10.1007/s00299-015-1741-9

Mikuła A, Grzyb M, Tomiczak K, Rybczyński JJ (2018) Experimental and practical application of fern somatic embryogenesis. In: Fernández H (ed) Current advances in fern research. Springer, Cham, pp 121-137. https://doi.org/10.1007/978-3-319-75103-0_6

Murashige T, Skoog F (1962) A revised medium for rapid growth and bioassays with tobacco tissue cultures. Physiol Plant 15:473-497. https://doi.org/10.1111/j.1399-3054.1962.tb08052.x

Prakash MG, Gurumurthi K (2010) Effects of type of explant and age, plant growth regulators and medium strength on somatic embryogenesis and plant regeneration in Eucalyptus camaldulensis. Plant Cell Tissue Organ Cult 100:13-20. https://doi.org/10.1007/s1124 0-009-9611-1

Pryer KM, Schneider H, Smith AR, Cranfill R, Wolf PG, Hunt JS, Sipes SD (2001) Horsetails and ferns are a monophyletic group and the closest living relatives to seed plants. Nature 409:619622. https://doi.org/10.1038/35054555

Puigderrajols P, Mir G, Molinas M (2001) Ultrastructure of early secondary embryogenesis by multicellular and unicellular pathways in cork oak (Quercus suber L.). Ann Bot 87:179-189. https://doi. org/10.1006/anbo.2000.1317

Quiroz-Figueroa FR, Fuentes-Cerda CFJ, Rojas-Herrera R, LoyolaVergas VM (2002) Histological studies on the developmental stages and differentiation of two different somatic embryogenesis systems of Coffea arabica. Plant Cell Rep 20:1141-1149. https:// doi.org/10.1007/s00299-002-0464-X

Taylor MG, Vasil IK (1996) The ultrastructure of somatic embryo development in pearl millet (Pennisetum glaucum; Poaceae). Am J Bot 83:28-44. https://doi.org/10.1002/j.1537-2197.1996.tb138 71. $\mathrm{x}$

Verdeil JL, Hocher V, Huet C, Grosdemange F, Escoute J, Ferriere N, Nicole M (2001) Ultrastructural changes in coconut calli associated with the acquisition of embryogenic competence. Ann Bot 88:9-18. https://doi.org/10.1006/anbo.2001.1408

Wang Y-H, Bhalla PL (2004) Somatic embryogenesis from leaf explants of Australian fan flower, Scaevola aemula R. Br. Plant Cell Rep 22:408-414. https://doi.org/10.1007/s00299-003-0707-5

Williams EG, Maheswaran G (1986) Somatic embryogenesis: factors influencing coordinated behaviour of cells as an embryogenic group. Ann Bot 57:443-462. https://doi.org/10.1093/aob/mcg002

You XL, Yi JS, Choi YE (2006) Cellular change and callose accumulation in zygotic embryos of Eleutherococcus senticosus caused by plasmolyzing pretreatment result in high frequency of single-cellderived somatic embryogenesis. Protoplasma 227:105-112. https ://doi.org/10.1007/s00709-006-0149-3 